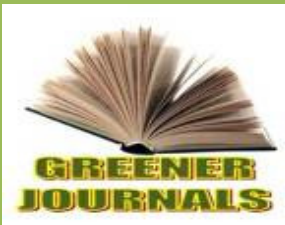

\title{
Study on Performance Evaluation of Tomato (Lycopersicon esculentum Mill.) Varieties Under Off-Season Condition at Teppi, South Western Part of Ethiopia
}

\section{Shamil Alo*1, Abebe Gezahegn², Wakjira Getachew ${ }^{3}$}

\author{
1\& 3Teppi National Spices Research Center, Po.Box 34, Teppi, Ethiopia. \\ ${ }^{2}$ Melkassa Agricultural Research Center,P.o.Box 436 ,Adama,Ethiopia.
}

\section{ARTICLE INFO}

ABSTRACT
Article No.: 032317045

DOI: 10.15580/GJAS.2017.5.032317045

Submitted: $23 / 03 / 2017$

Accepted: $28 / 03 / 2017$

Published: 30/07/2017

${ }^{\star}$ Corresponding Author

Shamil Alo

E-mail: shamilalo99@gmail.com

Keywords:

Adaptability, Improved Tomato

Varieties, Teppi
The cultivated tomato (Lycopersicon esculentum Mill.) is world's second most important vegetable after potato in terms of production. The major tomato producing regions of Ethiopia are Oromiya, Amhara, Tigray and S.N.N.P. The crop is cultivated under irrigation largely in the rift valley areas.

Ten released tomato varieties of different growth habit and type were brought from Melkassa agricultural research center and evaluated in randomized complete block design with three replication during 2007 and 2008 cropping season at Teppi. The experiment was carried out to test the adaptability of improved tomato varieties and identify and select the best high yielding and pest and disease resistant/ tolerant variety/ies for target area. The mean yield was ranged from 168.16 for Bishola to 256.2 for melka salsa.Based on mean yield,Melka salsa,Challi,Fetan,Metadel,Cochoro and Miya gave highest yield.The mean days to $50 \%$ flowering was ranged 54.333 for Miya to 83.667 days for Bishola. The mean days to $50 \%$ fruit setting was ranged 72.333 for Melkashola to 80 days for Eshet. The mean number of fruits per cluster was ranged 2.1333 for Challi to 2.9333 for Metadel and Miya. The mean number of cluster per plant was ranged $\mathbf{8 . 2 6 7}$ for Fetan to $\mathbf{1 7 . 6}$ for Melkasalsa.The mean marketable yield $\mathrm{kg} / \mathrm{plot}$ ranged from $\mathbf{7 . 5 6 7}$ for Bishola to $\mathbf{1 5 . 2 3}$ for Challi. The mean unmarketable yield $\mathrm{kg} /$ plot ranged from 3.33 for Melkashola to 6.3533 for Fetan. The mean total yield $\mathrm{kg} / \mathrm{plot}$ ranged from 13.117 for Bishola to 20.113 for Challi. The mean Average fruit weight was ranged from 41.444 for Melkasalsa to 167.444 for Bishola. Challi,Fetan,Metadel,Cochoro,Miya and ARP are more suitable for farmers due to their large fruit size.Further study should be carried out with improved varieties to improve tomato production under well established irrigation facility and disease and insect pest control. 


\section{INTRODUCTION}

The cultivated tomato (Lycopersicon esculentum Mill.) is world's second most important vegetable after potato in terms of production (Yibekal, 2009)[1] The major tomato producing regions of Ethiopia are Oromiya, Amhara, Tigray and S.N.N.P. The crop is cultivated under irrigation largely in the rift valley areas. The bulk of tomato production in the country is concentrated in river valleys and lakes especially in the Awash Valley. The crop is also produced in rainfed condition in some regions of the country. According to [2] report, the area coverage in tomato during meher season is around 7237.35ha with total production of $55,5742.79 q$ where Oromiya region being the highest in area coverage followed by S.N.N.P., Amhara and Tigray regions.

Considering the significant value of the crop, emphasis has been given by the national vegetable crops research program in the country to improve yield and quality of fresh market and processing tomato in order to satisfy the demands of both local and export markets.[3] A number of improved varieties and other agronomic packages have been recommended resulting in improvement of production and productivity of the crop in Ethiopia. But Still the national average yield of tomato in Ethiopia is 7.6 ton/ha [2] which is incomparable with the average yield of other countries such as China, USA, Turkey, India, Egypt, Italy and Spain with average yield of $22.67,80.61,35.81,18.61,40.00$ and 76.35 ton/ha in that order [4]

With the start of tomato research in the late 1969 to 2000, different tomato lines were imported from different seed companies and AVRDC and tested in different seasons such as rainy season, dry season and across locations in various research centers with the aim to identify cultivars that are suitable to different growing seasons and locations. Processing types with high stand establishment and survival rate were found both in the dry-season and rainy season, but the yield potential in the dry season was superior to that in the rainy season [3]. But, then after, variety development has been conducted mainly in central rift valley areas in the dry season and limited information is available regarding performance of the released tomato varieties in different agro-ecologies especially under rainfed conditions.

Currently, tomato production is concentrated in the dry season using irrigation mainly in the central rift valley areas of Ethiopia resulting in frequent price fluctuation. Some farmers in Oromiya, S.N.N.P., Amhara and Tigray regions use to produce tomato in rainfed condition [2]. Therefore, information regarding the performance in productivity of released tomato varieties in different agro-ecologies under irrigated and rainfed condition aids to recommend tomato varieties with better performance for different production seasons. To advance improvement of crop productivity in different localities, continual identification of the best and suitable crop technologies appeared to be essential. This can be achieved, through adaptability tests and generation of new technologies.

Keeping this in view, the present study was conducted at Teppi National Spices Research Center to test the performance of released tomato varieties for their adaptability in different agro-ecologies under irrigated condition.

\section{MATERIALS AND METHODS}

\subsection{Experimental Site}

The experiment was conducted at Teppi National Spices Research Center $1.5 \mathrm{~km}$ away from main Teppi town,during 2015/2016 cropping seasons. Teppi located in south western Ethiopia in SNNP Regional State at an elevation of 1200 meter above sea level and it is situated at Latitude of $7^{\circ} 10,54.5^{\prime \prime}$ and with a Longitude of $35^{\circ} 25^{\text {, }}$ 04.3-28.2. E of Ethiopia.The research station receive an annual average rainfall of $1559 \mathrm{~mm}$ with maximum and minimum temperatures of $29.7^{\circ} \mathrm{C}$ and $15.5^{\circ} \mathrm{C}$ ,respectively. The soil of experimental site is reddish brown sandy clay loam classified as nitosol with $\mathrm{PH}$ range of 5.60 to 6.0 (GISAM,2012)

\subsection{Experimental Materials and Design}

The experiment was based on ten released varieties of tomato which were obtained from Melkassa Agricultural Research center. Randomized complete block design with three replications was used to conduct the experiment. Seeds were planted on seed bed by drilling and were thinned to $5 \mathrm{~cm}$ and $15 \mathrm{~cm}$ between plants and between rows respectively 1 week after emergence and transplanted to main field after 30 days in spacing of $30 \mathrm{~cm}$ and $100 \mathrm{~cm}$ between plants and between rows respectively. The inter row spacing was $1 \mathrm{~m}$, while the intra row spacing was $0.3 \mathrm{~m}$, giving population density of 33333.33 plants per hectare. Fertilizers were applied at the rate of $200 / 100 \mathrm{~kg} / \mathrm{ha}$ DAP/Urea. Urea was applied in split (half at planting and the other half at $1 \& 1 / 2$ month after transplanting). Description of the experimental materials with their yield potential is shown in Table-1 below. 
Table I: Description of ten tomato Varieties with their agro-ecological adaptations

\begin{tabular}{|c|c|c|c|c|c|c|c|}
\hline Variety & $\begin{array}{l}\text { Growth } \\
\text { habit }\end{array}$ & $\begin{array}{l}\text { Maturity } \\
\text { days }\end{array}$ & Fruit shape & $\begin{array}{l}\text { Av.fruit } \\
\text { weight(gm) }\end{array}$ & $\begin{array}{l}\text { Av.yield } \\
\text { qt/ha }\end{array}$ & $\begin{array}{l}\text { Year of } \\
\text { release }\end{array}$ & Purpose \\
\hline Melkashola & Determinate & $100-120$ & Cylinderical & $80-70$ & 430 & 1998 & $\begin{array}{l}\text { Processing and } \\
\text { fresh market }\end{array}$ \\
\hline Melkasalsa & Determinate & $100-110$ & Pear & $40-50$ & 450 & 1998 & $\begin{array}{l}\text { Processing and } \\
\text { fresh market }\end{array}$ \\
\hline Challi & Determinate & $85-100$ & Square & $80-90$ & 430 & 2007 & $\begin{array}{l}\text { Processing and } \\
\text { fresh market }\end{array}$ \\
\hline Cochoro & Determinate & $85-90$ & Square & $70-80$ & 463 & 2007 & $\begin{array}{l}\text { Processing and } \\
\text { fresh market }\end{array}$ \\
\hline Eshet & Indeterminate & $75-80$ & $\begin{array}{l}\text { Slightly } \\
\text { flatten }\end{array}$ & $130-140$ & 394 & 2005 & Fresh market \\
\hline Metadel & Indeterminate & $75-90$ & $\begin{array}{l}\text { Slightly } \\
\text { flatten }\end{array}$ & $90-140$ & 345 & 2005 & Fresh market \\
\hline Fetan & Determinate & $75-80$ & Cylinderical & $110-120$ & 454 & 2005 & Fresh market \\
\hline Bishola & Determinate & $85-90$ & $\begin{array}{l}\text { Slightly } \\
\text { cylinderical }\end{array}$ & $140-150$ & 340 & 2005 & Fresh market \\
\hline Miya & Semi-determ & $90-100$ & Plum & $75-80$ & 471 & 2007 & Fresh market \\
\hline ARP & Determinate & $75-80$ & Cylinderical & & 395 & 2012 & Fresh market \\
\hline
\end{tabular}

Source: MoA Variety Registry Book (1998-2012)

\subsection{Data Collected}

The middle two rows $\left(7.8 \mathrm{~m}^{2}\right)$ were used for data collection and harvested at maturity. Individual plant base data as well as plot base data were collected on Twelve traits of tomato varieties. Data collected were, stand count at $1 \& 1 / 2$ after transplanting, stand count at harvest, $50 \%$ days to flowering, no of fruits/cluster, marketable fruit number and yield at each harvest $(\mathrm{kg}) / \mathrm{plot}$, unmarketable fruit number and yield $\mathrm{kg} / \mathrm{plot}$ at each harvest ( insect damaged, decayed, sunburn, bird damaged, cat face, blossom end rot, crack, zipper and others), Fruit quality (average weight $(\mathrm{gm})$ of 10 representative fruits, juice volume $(\mathrm{ml})$ of same fruits, TSS\%, firmness, color and shape) were determined at pick harvesting time usually at second or third harvest. Disease incidence and severity was determined using established procedure. Some important metrological data including mean monthly rain fall $(\mathrm{mm})$, mean maximum and minimum monthly temperature, mean \% relative humidity and soil type were recorded.

\subsection{Statistical Analysis}

All necessary data were recorded and being subjected to analysis. Analysis of variance was performed using the ANOVA procedure of SAS Statistical Software. Effects were considered significant in all statistical if the Pvalues were $<0.05$. Means were separated using Least significant difference test.

\section{RESULT AND DISCUSSION}

The analysis of variance for the 10 characters studied is given in Table 2. All the characters showed significant $(p<0.05)$ difference among the tested varieties. The significance of varieties difference indicates the presence of variability for each of the characters among the tested entries..

Statistical analysis showed significant differences for yield among the varieties. The mean yield was ranged from 168.16 for Bishola to 256.2 for melka salsa.Based on mean yield,Melka salsa,Challi,Fetan,Metadel,Cochoro and Miya gave highest yield.The mean days to $50 \%$ flowering was ranged 54.333 for Miya to 83.667 days for Bishola. The mean days to $50 \%$ fruit setting was ranged 72.333 for Melkashola to 80 days for Eshet. The mean number of fruits per cluster was ranged 2.1333 for Challi to 2.9333 for Metadel and Miya. The mean number of cluster per plant was ranged 8.267 for Fetan to 17.6 for Melkasalsa.The mean marketable yield $\mathrm{kg} / \mathrm{plot}$ ranged from 7.567 for Bishola to 15.23 for Challi. The mean unmarketable yield $\mathrm{kg} / \mathrm{plot}$ ranged from 3.33 for Melkashola to 6.3533 for Fetan. The mean total yield $\mathrm{kg} /$ plot ranged from 13.117 for Bishola to 20.113 for Challi. The mean Average fruit weight was ranged from 41.444 for Melkasalsa to 167.444 for Bishola.

All varieties showed significant difference for $50 \%$ flowering, $50 \%$ fruit setting,number of fruit per cluster,number of cluster per plant,marketable yield $\mathrm{kg} /$ plot, un marketable yield $\mathrm{kg} /$ plot,total yield $\mathrm{q} / \mathrm{ha}$ and average fruit weight. Melkasalsa,Challi,Fetan,Metadel,Miya and Cochoro, gave highest yield followed by Melkashola,Eshet and Bishola respectively. Melkssalsa have highest number of fruits per cluster followed by Melkashola.Miya and Melkasalsa have highest number of cluter per plant followed by Melkashola and cochoro.Melkasalsa and Challi gave highest yield quintal per hectare.Bishola and Cochoro have highest average fruit weight followed by Metadel and Challi. Fruit yield per hectare showed significant difference among the varieties. The highest marketable yield was obtained by Melka salsa and the 
least yield was recorded by Bishola.This result is in line with the result which reported by [5]

Table II: The mean squares for different sources of variation and the corresponding CV (\%) for the 10 characters studied at Teppi in 207/2008

\begin{tabular}{lllllll}
\hline Trait & Variety & Replication & Error & CV & Mean & $\mathrm{R}^{2}$ \\
\hline Days to 50\% Fowering & 345.21 & 278.6 & 73.3 & 13.21 & 64.8 & 0.56 \\
Days to 50\% fruit setting & 33.8 & 194.6 & 23.68 & 5.68 & 74.8 & 0.43 \\
No.of fruits /cluster & 5.03 & 0.77 & 0.12 & 11.85 & 2.95 & 0.9 \\
No.of cluster /plant & 65.55 & 6.9 & 5.71 & 18.58 & 12.86 & 0.73 \\
Marketable yield kg/plot & 30.81 & 181.63 & 15.12 & 33.15 & 11.72 & 0.63 \\
UMarketable yield kg/plot & 6.02 & 7.67 & 0.22 & 11.28 & 4.21 & 0.89 \\
Total yield Kg/plot & 35.12 & 91.34 & 10.38 & 18.73 & 17.19 & 0.63 \\
Total yield Qt/ha & 4940.49 & 13248.19 & 1711.07 & 18.94 & 218.39 & 0.63 \\
Firmness & 6.51 & 5.06 & 0.85 & 21.35 & 4.33 & 0.67 \\
AVFW & 9325.15 & 1012.23 & 238.44 & 13.17 & 117.2 & 0.9 \\
\hline
\end{tabular}

\section{SUMMERY AND CONCLUSION}

The cultivated tomato (Lycopersicon esculentum Mill.) is world's second most important vegetable after potato in terms of production [1]. The major tomato producing regions of Ethiopia are Oromiya, Amhara, Tigray and S.N.N.P. According to [2] report, the area coverage in tomato during meher season is around 7237.35ha with total production of $55,5742.79 q$ where Oromiya region being the highest in area coverage followed by S.N.N.P., Amhara and Tigray regions.

A number of improved varieties and other agronomic packages have been recommended resulting in improvement of production and productivity of the crop in Ethiopia. But Still the national average yield of tomato in Ethiopia is 7.6 ton/ha [2] which is incomparable with the average yield of other countries such as China, USA, Turkey, India, Egypt, Italy and Spain with average yield of $22.67,80.61,35.81,18.61,40.00$ and 76.35 ton/ha in that order [4].

With the start of tomato research in the late 1969 to 2000, different tomato lines were imported from different seed companies and AVRDC and tested in different seasons such as rainy season, dry season and across locations in various research centers with the aim to identify cultivars that are suitable to different growing seasons and locations. These resulted in the recommendation of several tomato varieties for the tomato growing regions of the country .

To advance improvement of crop productivity in different localities, continual identification of the best and suitable crop technologies appeared to be essential. This can be achieved, through adaptability tests and generation of new technologies.

Ten released tomato varieties were tasted at Teppi ARC in randomized complete block design with three replication during 2007/2008 cropping season. The experiment was carried out to test the adaptability of improved tomato varieties and identify and select the best high yielding, pest and disease resistant/tolerant variety/ies for the target area.

Significance differences were observed for yield and 9 characters studied(days to $50 \%$ flowering, days to $50 \%$ fruit setting,number of fruits per cluster, number of cluster per plant,marketable yield $\mathrm{kg} /$ plot,unmarketable yield $\mathrm{kg} /$ plot,total yield $\mathrm{kg} /$ plot,total yield $\mathrm{qt} / \mathrm{ha}$,firmness, average fruit weight).

The mean yield was ranged from 168.16 for Bishola to 256.2 for melka salsa.Based on mean yield,Melka salsa,Challi,Fetan,Metadel,Cochoro and Miya gave highest yield.The mean days to $50 \%$ flowering was ranged 54.333 for Miya to 83.667 days for Bishola. The mean days to $50 \%$ fruit setting was ranged 72.333 for Melkashola to 80 days for Eshet. The mean number of fruits per cluster was ranged 2.1333 for Challi to 2.9333 for Metadel and Miya. The mean number of cluster per plant was ranged 8.267 for Fetan to 17.6 for Melkasalsa.The mean marketable yield $\mathrm{kg} / \mathrm{plot}$ ranged from 7.567 for Bishola to 15.23 for Challi. The mean unmarketable yield $\mathrm{kg} / \mathrm{plot}$ ranged from 3.33 for Melkashola to 6.3533 for Fetan. The mean total yield $\mathrm{kg} /$ plot ranged from 13.117 for Bishola to 20.113 for Challi. The mean Average fruit weight was ranged from 41.444 for Melkasalsa to 167.444 for Bishola. In general Melka salsa,Challi,Fetan,Metadel,Cochoro,Miya and ARP had high yield than other varieties. Melka salsa, Challi,Fetan and Metadel are more suitable for farmers due to their highest tield compared to other varieties.Further study should be carried out with improved varieties to improve tomato production under well established irrigation facility and disease and insect pest control. 
Table III: Summary of mean yield ( $q / h a)$ of varieties

\begin{tabular}{|c|c|c|c|c|c|c|c|c|c|c|}
\hline Treatment & $\begin{array}{c}\text { Days to } \\
50 \% \\
\text { Fowering }\end{array}$ & $\begin{array}{c}\text { Days to } \\
50 \% \text { fruit } \\
\text { setting }\end{array}$ & $\begin{array}{l}\text { No.of } \\
\text { fruits } \\
\text { /cluster }\end{array}$ & $\begin{array}{l}\text { No.of } \\
\text { cluster } \\
\text { /plant }\end{array}$ & $\begin{array}{c}\text { Marketable } \\
\text { yield kg/plot }\end{array}$ & $\begin{array}{l}\text { UMarketable } \\
\text { yield kg/plot }\end{array}$ & $\begin{array}{l}\text { Total yield } \\
\text { Kg/plot }\end{array}$ & $\begin{array}{c}\text { Total yield } \\
\text { Qt/ha }\end{array}$ & Firmness & AVFW \\
\hline Metadel & $63.667 b$ & $75 a b c$ & $2.93 c$ & $12.067 d$ & 10.933bcd & $4.1167 c$ & 18.3ab & 234.61ab & $3 d$ & $146.867 \mathrm{bc}$ \\
\hline $\begin{array}{c}\text { Miya } \\
\text { Cochoro } \\
\text { Bishola } \\
\text { Challi }\end{array}$ & $\begin{array}{c}54.333 c \\
63.333 b \\
83.667 a \\
68 b\end{array}$ & $\begin{array}{c}77.667 \mathrm{ab} \\
74.667 \mathrm{bc} \\
75 \mathrm{abc} \\
73.333 \mathrm{bc}\end{array}$ & $\begin{array}{c}2.93 \mathrm{c} \\
2.53 \mathrm{def} \\
2.33 \mathrm{efg} \\
2.13 \mathrm{~g}\end{array}$ & $\begin{array}{c}17.6 a \\
14.667 b c \\
11.533 d \\
8.267 e\end{array}$ & $\begin{array}{c}12.334 a b c \\
12.533 a b c \\
7.567 \mathrm{~d} \\
15.230 \mathrm{a}\end{array}$ & $\begin{array}{c}3.7 \mathrm{cde} \\
3.5833 \mathrm{de} \\
3.5 \mathrm{e} \\
5.7167 \mathrm{~b}\end{array}$ & $\begin{array}{c}16.867 a b c d \\
17.283 a b c \\
13.117 d \\
20.113 a\end{array}$ & $\begin{array}{c}216.25 \mathrm{abcd} \\
221.58 \mathrm{abc} \\
68.16 \mathrm{~d} \\
250.47 \mathrm{ab}\end{array}$ & $\begin{array}{c}4.3333 b c \\
5 b \\
3.6667 \mathrm{~cd} \\
6.3333 a\end{array}$ & $\begin{array}{c}95.444 \mathrm{e} \\
152.556 \mathrm{ab} \\
167.444 \mathrm{a} \\
118.333 \mathrm{~d}\end{array}$ \\
\hline Fetan & $65.333 b$ & $73.667 b c$ & $2.2 \mathrm{fg}$ & $8.767 e$ & 14.133ab & $6.3533 a$ & $19.818 a$ & $240.97 a b$ & $3 d$ & $130.667 d$ \\
\hline $\begin{array}{l}\text { Melka } \\
\text { Salsa }\end{array}$ & $63.333 b$ & $73.667 \mathrm{bc}$ & $5 a$ & $17.6 a$ & 12.967abc & $4.1 c$ & 19.983a & $256.20 a$ & $5 b$ & $41.444 \mathrm{~g}$ \\
\hline $\begin{array}{l}\text { Melka } \\
\text { Shola }\end{array}$ & $61.667 b c$ & $72.333 c$ & $4.13 b$ & $15.067 b$ & $10.6 \mathrm{bcd}$ & $3.333 \mathrm{e}$ & 15.683bcd & 201.06bcd & 4.3333bc & $65.111 f$ \\
\hline $\begin{array}{c}\text { Eshet } \\
\text { ARP }\end{array}$ & $\begin{array}{c}65 b \\
59.667 b c\end{array}$ & $\begin{array}{c}80 \mathrm{a} \\
72.667 \mathrm{bc}\end{array}$ & $\begin{array}{l}2.73 \mathrm{~cd} \\
2.6 \mathrm{cde}\end{array}$ & $\begin{array}{c}12.4 \mathrm{~cd} \\
10.667 \mathrm{de}\end{array}$ & $\begin{array}{c}9.2 \mathrm{~cd} \\
11.8 \mathrm{abc}\end{array}$ & $\begin{array}{l}4.0167 \mathrm{~cd} \\
3.766 \mathrm{cde}\end{array}$ & $\begin{array}{c}14.217 \mathrm{~cd} \\
16.567 \mathrm{abcd}\end{array}$ & $\begin{array}{c}182.26 \mathrm{~cd} \\
212.38 \mathrm{abcd}\end{array}$ & $\begin{array}{c}3.6667 \mathrm{~cd} \\
5 b\end{array}$ & $\begin{array}{c}123.333 d \\
130.889 c d\end{array}$ \\
\hline $\begin{array}{l}\text { CV } \\
\text { Isd }\end{array}$ & $\begin{array}{c}11.88 \\
8.9415\end{array}$ & $\begin{array}{c}5.85 \\
5.0829\end{array}$ & $\begin{array}{c}10.65 \\
0.3656\end{array}$ & $\begin{array}{l}16.71 \\
2.4971\end{array}$ & $\begin{array}{l}29.84 \\
4.0654\end{array}$ & $\begin{array}{l}10.34 \\
0.507\end{array}$ & $\begin{array}{l}18.81 \\
3.7572\end{array}$ & $\begin{array}{l}19.87 \\
50.41\end{array}$ & $\begin{array}{c}19.19 \\
0.9663\end{array}$ & $\begin{array}{c}11.84 \\
16.1\end{array}$ \\
\hline
\end{tabular}




\section{ACKNOWLDGEMENTS}

My special thanks go to Teppi National Spices Research Center for financial support. Grateful acknowledgements are also due all staff members for their strong moral and technical support.

\section{REFERENCES}

[1] Yibekal, A.A. (2009). Managing the soil water balance of hot pepper (Capsicum annuum L.) to improve water productivity. University of Pretoria, the requirements for the degree Doctor of Philosophy in Horticultural Science [2] CSA. (2013). Report on area and production of major crops. Statistical bulletin.

[3] Lemma, D. (2002). Tomato research experiences and production prospects, Ethiopian Agricultural Research Organization Research report, No.43

[4] FAOSTAT. 2010. Rom United Nations Food and Agriculture Organization.

[5] Shushay C, and Haile Z.Evaluation of Tomato varieties for fruit yield and yield components in western lowland of Tigray,Northern Ethiopia.

Cite this Article: Shamil A, Abebe G, Wakjira G (2017). Study on Performance Evaluation of Tomato (Lycopersicon esculentum Mill.) Varieties Under Off-Season Condition at Teppi, South Western Part of Ethiopia. Greener Journal of Agricultural Sciences, 7(5): 120-125, http://doi.org/10.15580/GJAS.2017.5.032317045. 